\title{
Moulding the democratic citizen of the future: On the discourses and practices of film education in Sweden
}

\author{
Malena Janson* - Stockholm University, Sweden
}

\begin{abstract}
The aim of this article is to convey the history, practices and central discourses of film education in Sweden. The first part takes the pioneering efforts, dating back to 1908 , as a starting point for describing the development of nationwide school cinema, financed by public funding and coordinated by the Swedish Film Institute. As I will argue, film education in Sweden is primarily used as a tool for fostering democratic citizens. The second part of the article discusses the main discourses of this film education model - that is, what constitutes this democratic citizen and how these are conveyed. An analysis of film study guides produced by the Swedish Film Institute between 1988 and 2018 demonstrates that the main aim of what could be referred to as the Swedish model is to foster the basic principles of human rights as defined by the United Nations, and that this is achieved in a very convincing manner.
\end{abstract}

Keywords: film education; national discourses; film study guides; Swedish school cinema

\section{Introduction}

In her article 'Education à l'image and Medienkompetenz: On the discourses and practices of film education in France and Germany' in the first issue of Film Education Journal, Bettina Henzler (2018) compares two fundamentally different ways of using film education. Henzler demonstrates how German film education is anchored in politics of media education and around notions of media literacy, while in France, cinema is a field of art education centred on film as an art form. Furthermore, Henzler (ibid.) traces these approaches to the different historical, political and artistic development of the two countries.

The aim of this article is to explore a third possible film educational approach, demonstrated here within a Swedish context, which utilizes fiction film as a moral educational tool, with the more or less explicitly declared intention of moulding students into 'good' - that is, democratic - citizens. As will be developed in the first part of the article, this largely instrumental use of film dates back to the construction of the welfare state in the 1940s, when the first Swedish children's films were produced as a counter to Hollywood films that were dismissed as being morally reprehensible by many (adults). In the second part, the article indicates what constitutes this ideal Swedish citizen, that is, what exemplary qualities are emphasized for students, and how such qualities are pursued. This is demonstrated by examining samples of film study guides produced by the Swedish Film Institute in four different decades: in 1988, 1998, 
2008 and 2018. Finally, some questions regarding this film education model are raised, although answering such questions decisively is beyond the scope of this article.

Hopefully, the article as a whole will add to the mapping and the understanding of the history, discourses and practices of film education in Europe. The intention is not to decide which way, or model, is preferable, but rather to highlight the national differences and, in the long run, to contribute to our opportunities to learn from one another.

\section{A brief history of film education in Sweden}

As in many other countries, the introduction of film as a medium in Sweden led almost instantaneously to debates concerning its allegedly harmful effects upon the minds of young and 'fragile' audiences. As a result, in 1911 a national film censorship board was established with a duty to inspect every film intended for public exhibition and, if approved, to provide each with an age restriction (Janson, 2007). In parallel with this tendency, however, favourable and progressive voices were also heard in defence of the new medium. In 1908, one of the pioneers of Swedish film education, Frans von Scheele, gave a speech in Stockholm calling attention to the great educational opportunities of cinema, and advocating for visits to cinemas to be part of the school curriculum (Eriksson, 2016). Von Scheele also stressed that screenings should be 'introduced and followed up by lectures or discussions with the children in the classroom' (von Scheele, 1908, cited in Eriksson, 2016). This led to the first film educational experiments in Stockholm in the 1910s, where students attended cinema screenings during school hours together with their teachers (Exadaktilou Wallenrohde, 2018).

As cinema repertoire gradually changed, consisting eventually almost entirely of entertainment films, film education practices also changed, moving into schools, which were then encouraged to buy their own film projectors (Lindgren et al., 2012). The leading Swedish film company, Svensk Filmindustri, started compiling catalogues of 'suitable' films for young audiences to supply to schools, and in 1921 they also announced the establishment of a specific department devoted to the production of school films. The content of these films was documentary, most often to be used as a pedagogic aid in subjects such as natural science or geography (Dahlquist, 2008). The arguments behind the use of films in school were that they could 'visualize processes in nature, such as seasonal changes, growth in plants, insect processes, pollination, and adaptation of plants to different light during the day' - films could reveal 'the hitherto unseen', or what was 'hidden for our eyes' (Lindgren et al., 2012). The production and distribution of specific educational school films transformed the film education practice into a pedagogic approach where cinema was regarded as an instrumentalized instructional tool, a medium to teach and learn through. Anne-Li Lindgren (2009) has demonstrated how school films during the 1930s and early 1940s were permeated by a national discourse, inculcating a collective pride in the Swedish motherland's beautiful and powerful nature and rich natural resources.

Although film had been an educational tool in Swedish schools for decades, it was not until 1962 that the word 'film' was mentioned in curricula for the first time, namely in connection with the introduction of the concept of the language of moving images. The use of film, it was stated, is particularly relevant for studying the Swedish language, since it facilitates the understanding of storytelling and dramaturgy (Exadaktilou Wallenrohde, 2018). Research on the power of this new ingredient in the curricula still needs to be done, not least to see if it changed the approach towards film education, perhaps generating interest in screening and discussing fiction film during 
school hours. However, a quick survey of issues of the cinema journal Filmrutan from the 1960s suggests that there definitely existed aspirations in that direction.

The real breakthrough for film education practice as we know it, however, came in the 1980s, when fiction films in regular distribution became part of school education to a noticeable extent. This was an attempt to meet the problems that came with new technologies, such as VHS and cable television, which led to a national debate, the so-called Videovåldsdebatten ('video violence debate'), on young people's rapidly growing access to media violence (Holmberg, 2016). For example, in a pioneering project that has drawn a lot of attention, the Swedish language teacher Olle Holmberg watched and discussed violent films together with a group of teenage boys in upper secondary school. The project went on for several months, included various activities and was eventually documented in the book Videovåld och undervisning ('Video violence and school education') (Holmberg, 1988).

The Swedish Film Institute (SFI) had a different, and seemingly successful, way of approaching the video violence debate. Instead of discussing the attraction of filmic violence for young people, the SFI tried to shift the focus of the debate by emphasizing the positive functions of cinema. The SFI's Elisabet Edlund, for example, stated that there are many films 'produced for children and youth that are amusing, upsetting and enriching. Films that, just like literature and music, should be part of school's everyday life' (Edlund, 1986, cited in Exadaktilou Wallenrohde, 2018). The persistent lobbying for a new, favourable attitude towards the film medium bore fruit: in 1986, the SFI was assigned state funding of 6 million SEK (approximately 600,000 euros) to establish so-called 'school cinema' in municipalities and regions across the country. School cinema typically involves cinema screenings at local theatres, followed by classroom discussions (Viklund and Österholm, 2001). This significant development is usually perceived to be the starting point of what is considered to be 'modern film education' in Sweden, and ever since, the SFI has had the government's commission to coordinate film education practice nationwide. The department devoted to this today is called Film i skolan ('Film in Schools') and consists of three employees in 2019. Besides distributing the state funding (3.3 million SEK in 2018), Film i skolan's main activities are dissemination of information and the production of extensive film study guides primarily for teachers (discussed in more detail below).

\section{Aims and practices of film education in Sweden}

The English version of the SFI's website states that:

Through its Film in Schools initiative, the Film Institute supports film education in schools and municipalities throughout Sweden. The aim is to provide quality film experiences for children and young people, and to encourage them to deepen their knowledge of film and to express themselves through film as a medium. (Swedish Film Institute, n.d.)

This information clearly expresses that the aim of film education, according to the SFI, is twofold: first, to provide experiences and foster knowledge of high-quality film, and second, to enable children and young people to learn the foundations of film-making. Accordingly, the film education model of the SFI seems to combine what Henzler describes as a French cinephile approach with a German Medienkompetenz approach (Henzler, 2018). As Alain Bergala suggests, children should be taught 'cultural heritage and film appreciation' (Bergala, 2002, cited in Henzler, 2018: 27), while also learning the skills expressed by Dieter Baacke as 'competencies in communicating with media', 
including 'creative practice (Mediengestaltung)' (Baacke, 2004, cited in Henzler, 2018: 26).

Thus, in theory at least, the ambitions of Swedish film education on a national level are similar to those elsewhere in Europe. A number of studies show, however, that there is in fact a gap between the theory and practice of film education (Janson, 2008; Rozenkrantz and Mund, 2014; Lindgren et al., 2012), and that the cinephile and the Medienkompetenz approaches frequently are put aside to make room for another, third approach, directed at influencing students' basic opinions and outlook. Here, cinema is used most frequently in close connection with wider curricula, hence with the principal aim of addressing subjects other than the film medium (Exadaktilou Wallenrohde, 2018). In practice, the standard approach of film education, or school cinema, is that students visit a cinema together with their teacher during school time. The films chosen to be part of school cinema are usually picked by a team of teachers from a catalogue of suitable films, curated by someone working with children and youth culture at the municipal or regional office. The supply of films usually consists of recent titles in regular distribution and/or shown at film festivals, most often fiction films, ranging from Hollywood blockbusters to low-budget dramas from Ethiopia or Palestine. Following the film, a moderated debate or discussion about the film is organized in the classroom, frequently structured on the basis of a study guide provided by the SFI. The study guide is a five- to ten-page booklet including an extensive summary of the film, pictures, substantial descriptions of between four and six themes to discuss, suggestions for further reading and film credits. In this manner, school cinema is used as an educational instrument in a wide range of subjects, such as Swedish, history, religious studies, social science, geography and languages.

As noted in an article titled 'From instruction to reflection' by Lindgren et al. (2012: 151), contemporary film education in Sweden 'focuses on the social skills' by stimulating students' discussions of selected topics. Cinema is primarily used as an educational tool to encourage students' engagement in society with the purpose of getting them to discuss and reflect upon 'difficult' subject matter, such as poverty, child abuse and sexual assault. At the same time, as the article demonstrates, 'larger political and social lessons are taught and learned' (ibid.: 170). This tendency towards civic education within Swedish film education seems to have started with the premieres of large-scale Hollywood films about historical characters, such as Attenborough's Gandhi (1982) and Bertolucci's The Last Emperor (1987). In his PhD thesis, 'Att projicera det förflutna' ('Projecting the past'), Martin Karlsson (2011) claims that these 'basedon-a-true-story' films are often used as starting points for classroom discussions about value systems, beliefs and ethics, and seldom (if ever) about historical representation and truth claims.

The SFI has also sometimes launched major film educational projects focusing on a specific subject regarded as particularly urgent. To carry out this work, the SFI has occasionally received extra state funding. One example of this was in the late 1990s, when the outcome of a large survey indicated that more than a third of students in upper-level lower secondary schools in Sweden doubted that the Holocaust had taken place. This drew a considerable amount of attention in the media and politics and, among other consequences, led to a major effort devoted to information campaigns (Holmberg, 2016). One of the institutions that took action was the SFI, investing considerably in film educational projects related to the Holocaust. Numerous books, video cassettes, study guides and leaflets were produced and distributed to schools across the nation, resulting in a strong engagement (Viklund and Österholm, 2001). A similar campaign was carried out in connection with the premiere of Lukas Moodysson's 
Lilya 4-ever (2002), which depicts a young girl in Balticum falling victim to sex trafficking. After the film was screened in the Swedish parliament, a government decision was made that Lilya 4-ever was to be made part of school cinema in upper secondary schools for free. Across the country, students engaged in debates on gender equality, prostitution and social injustice, although Anna Sparrman (2006) doubts the general outcome of these debates. In her article 'Film as a political and educational device: Talk about men, male sexuality and gender among Swedish youth', Sparrman (ibid.) notes that classroom discussions about the film tended to construct a very one-sided and negative notion of men and male sexuality, which was far from fruitful. The main reason for this outcome, she argues, was that Lilya 4-ever was expressly promoted to schools as a political device to strengthen gender equality and, in the long run, to reduce sex trafficking. There was, therefore, 'a right way of seeing and interpreting it' (ibid.: 180). This problematic approach towards cinema has given rise to critiques by other scholars too, arguing that it also reduces the medium to its content alone, neglecting its cinematic form - that is, the media-specific properties (Rozenkrantz and Mund, 2014; Janson, 2008).

\section{Film education and children's cinema as 'fostering' tools}

There are clearly similarities between the Swedish variety of film education and the German approach, described by Henzler (2018) as a way partly of learning through film, prioritizing themes and content over form or aesthetic quality. The approach towards cinema in both cases is highly instrumental, based, as Henzler (ibid.: 18) describes the German approach, on 'a political conception of Medienbildung ... whose primary objective is explicitly civic education, politische Bildung ... as an opportunity for political, social and cultural involvement'. However, there are also differences, the most notable being the prominent inclinations of the Swedish approach towards fostering particular sociocultural perspectives. The reflections and discussions that students are encouraged to engage in after seeing a film are seldom open-ended for thoughts and ideas, but rather directed at one 'correct' conclusion, and hence strive for consensus. This is not just the case with large politically informed initiatives such as the pedagogic launch of Lilya 4-ever, but could also be said to be more or less the case with most Swedish film educational projects. Debates in class are supervised by a teacher, who is following a study guide from the SFI based on the value system formulated in the curriculum, in turn expressing the foundations of the Swedish democratic system. In short, there are almost exclusively 'right' answers to the questions raised by a film, and one of the main purposes of film education is to find these answers. Hence, film education in Sweden is often used as a way of making students think the 'correct' thoughts or, to use a somewhat more appealing expression, fostering good future citizens (as will be discussed below) (Janson, 2008). Accordingly, there is a risk that film education becomes a method to, first, wield an older generation's power over the younger, and, second, to circumscribe students' freedom of thought.

There are, I argue, explanations underlying this problematic 'fostering' approach to film education that can be discovered in Swedish film history, if observed through a perspective borrowed from childhood studies. Swedish children's cinema has a strong, long-standing tradition of depicting children as powerful agents, often struggling with difficult events and situations. This dates back to the film usually declared to be the first 'real' Swedish children's film (produced and distributed for, and thematically and aesthetically addressed to, a child audience), Rolf Husberg's The Children of Frosty Mountain (1945). Husberg's film is the story of seven orphan siblings who set 
off on a long and troublesome journey by foot, from a remote village in the north heading south. Despite the hardships, the older children never lose their hope and never give in to whining or fighting. Along their way, they encounter good people who help them (and even take the smaller boys and girls in as foster children), as well as bad people who deceive and try to rob them. Eventually, the whole little family find new, good homes and each of the children can look forward to a bright future. The film was based on a Swedish children's classic, a novel from 1907 by Laura Fitinghoff, and the adaptation was a great success among film critics as well as audiences for several decades. One of the main qualities that was universally applauded by critics was the depiction of the children, who appeared to be excellent role models for young audiences. In one newspaper, the pseudonymous critic Persevs declared: 'Imagine what a great education such a film constitutes! In contrast to all other rubbish whereby you stuff the minds of children' (Persevs, 1945, cited in Janson, 2007: 59). The 'rubbish' mentioned in the review most probably referenced the great number of Hollywood films that were screened for hordes of children as matinees on Sundays (Janson, 2007).

These Hollywood films were considered by many to be morally dubious at best, mentally harmful for children at worst, and were often debated in the media during the early and mid-1940s. An official report of the Swedish government, published in 1945 and entitled The Youth and the Amusements (SOU, 1945), claims the 'matinee problem' to be a serious issue, as the film medium's strong suggestive power leads children astray in life, making them forget about duties, education and their role in society. As a possible solution to the problem, the report suggested the provision of state funding for the production of high-quality, 'suitable' Swedish children's films. The report claimed that there was nothing wrong with the film medium per se, it was the content that was problematic. By depicting the right sort of stories, the medium's strong emotional impact could instead be used in a positive manner (Janson, 2007). The Children of Frosty Mountain can be understood as a response to this demand, not least in the way it represents young heroes who are 'good people', setting 'good examples' for young audiences, as the film critic Sweep put it (Sweep, 1945, cited in Janson, 2007: 53). Unsurprisingly, the film became the starting point of a long tradition of Swedish children's cinema depicting children as powerful agents and strong role models.

As I argued in 'Cinema of best intentions? 60 years of Swedish children's film as education and entertainment', the portrayals of these young role models clearly reflect contemporary ideas and ideals about children, that is, the discourses of childhood, circulating in society at the time (Janson, 2007). The mid-1940s was the heyday of the so-called Folkhem era, when the foundations of the Swedish political model were laid, and when children were regarded as the future of a prosperous Swedish society more than ever before or since. The two eldest siblings in The Children of Frosty Mountain, Ante and Maglena, can be seen to have all the characteristics one could wish for an ideal Swedish citizen: they are hard-working, honest, courteous, humble, economical, sober and clean, as well as considerate, loyal and generous towards those who are vulnerable.

Thus, ever since these early days of children's cinema in Sweden, fiction film has been utilized as an instrument to mould the young and impressionable generations into good citizens, and that at least in part explains why film education practices in Sweden are $-\mathrm{I}$ argue - most often permeated by the same 'fostering' agenda. Watching and discussing films during school hours inevitably becomes a means by which to implant certain typically 'Swedish' attitudes as a way of forming the ideal future citizens of Sweden. What characterizes these citizens will be explored in the next section. 


\section{Discourses in film study guides}

\section{Film study guides as research material}

The thirty or so film study guides published annually by the Swedish Film Institute and made available on their website are essential to the practice of film education across schools in Sweden. For many of the films presented as part of school cinema, there is an accompanying booklet, which teachers are encouraged to use as an introduction to the film before the cinema visit, as well as to serve as a support and a point of departure for classroom discussions. Since their inception, production of the film study guides has been one of the main activities for the Film in School department at the $\mathrm{SFI}$, and the shape and form of the texts have not changed much since the first study guide from 1988, which accompanied the Swedish film Seppan (1986), the earnest tale of a group of children living in a multicultural industrial area of Stockholm in the 1960s.

As described above, each study guide contains an extensive summary of the film, which is particularly helpful for teachers who have not been able to see the film before screening it for their students. The rest of the text is divided into four to six subjects, either expressly brought up by the film or inspired by it. These thematic explorations constitute the main part of the study guide, and they are usually introduced, developed and interspliced with questions directed at students, either to answer individually or, more often, to reflect upon or debate together in pairs, small groups, or with their whole class. Occasionally, creative tasks for students are suggested, such as 'draw a picture of ...', 'write a continuation of ...' or 'find out more about...'. Concluding the study guide are suggestions for further reading or viewing, such as books, articles, films, websites and television programmes. The study guides also include film production details, the name of the guide's author and the SFI's contact information.

For this article, 12 film study guides covering 30 years - three from each year of 1988, 1998, 2008 and 2018 - have been randomly selected for analysis. To ensure an adequate basis for comparison, however, the selection was made from study guides accompanying fiction films and recommended for lower secondary school (students aged between 13 and 16 years). The texts are written by a range of different authors, frequently freelance writers commissioned by the SFI, and they cover films from around the world. The early study guides (1988) were leaflets that could be ordered by schools by post and today are kept in the SFI archives. In 1998, all study guides were published in the film education journal Zoom. Since 2006, when Zoom went digital, all study guides are distributed by the SFI website as open access PDF files, meaning that the study guides from 2008 and 2018 have been downloaded from the internet for free.

The aim of my analysis is to explore what constitutes the Swedish 'ideal democratic citizen of the future', through an examination of what I consider to be the 'fostering' discourses of the film study guides. My main focus will be directed towards: (1) the meta-discursive elements, such as the instructions on how to use the study guide; (2) recurring themes and subject matter with which the texts encourage students to engage; and (3) the way the texts address the reader. Accordingly, my analysis explores questions such as: What are the conveyed intentions of the study guides?; What are the emerging topics?; How are these topics presented to the reader?; Are there any differences between study guides from different decades and, if so, what are they? By answering these questions, my intention is to give an account of the expected outcomes of film education as a practice in Sweden. A more complete examination would, of course, demand more thorough analysis of a larger proportion of study guides, and as such my aim here is rather to deliver an initial indication. 


\section{Meta-discursive ingredients}

Meta-discursive textual elements refer to aspects of a text that implicitly draw attention to the text itself. In this context, the concept is used to describe passages of text that expressly instruct the reader about how to utilize the SFI's study guides as part of the practice of film education. In the early texts (from 1988), there are distinct directions on 'How to use this booklet'. In the study guide for the Venezuelan drama film Little Revenge (1986), for example, the text states that 'this study guide contains facts and proposals for topics to discuss further on the basis of the film ... use the question formulations that you find most interesting and create a debate emerging from these' (Dahlén, 1988). In the study guide accompanying the Danish teen movie Friends Forever (1986), the text calls upon the reader (apparently a teacher) even more straightforwardly: 'This study guide addresses you, who are going to see and discuss the film Friends Forever together with a group of young people. The study guide aims to demonstrate how to open up and maintain a discussion about the film' (Viklund, 1988).

The study guides from 1998 and 2008 are designed like articles for a magazine (that is, Zoom), and the instructional meta-text is replaced by an introduction providing a very brief summary of the principal parts of the film and an overview of how these can be approached in the classroom. Since this is the highlighted opening, it is of vital importance for the text as a whole, and it gives directions about how to understand and use the film, as well as the study guide itself. According to the introduction of the study guide for the European co-production Second World War drama The Island on Bird Street (1997), the film 'brings up questions about oppression and resistance, empathy and moral courage', which, according to the author, are vital to discuss in the classroom (Westergren, 1998). The Danish 'girl power' film Fighter (2007), on the other hand, is suggested as a useful starting point for discussions on more colloquial topics. The introduction says that 'For lower secondary school pupils, the film is well-suited for reasoning about identity, gender issues, religion, representation and stereotypes' (Cojnby, 2008).

In 2018, the layout of the study guides changed to resemble information leaflets rather than articles in a magazine. As in 1988, there is an introductory paragraph with directions about how to use the text. Unlike 1988, however, the formulation is identical in most study guides and includes the following sentence: 'The study guide may be used as a preparation, a support, and as a help to draw out question formulations and discussions. Let the requisites of your pupils lead you' (Larsson, 2018; Pejkovic, 2018). This paragraph is followed by another, entitled 'The film and the curriculum', in which the themes of the film are connected with the curriculum, or with the Education Act. This is possibly intended as a means of further motivating teachers to use film as an educational tool during school hours, since it effectively says, 'the curriculum/ Education Act states that this is really important!' Interestingly, in all the study guides examined, the main emphasis of the paragraph 'The film and the curriculum' is on basic values and general democratic value systems, rather than on subject-related facts. For example, in the study guide accompanying the contemporary Swedish smalltown comedy Amateurs (2018):

The Education Act states that 'The internationalization of Swedish society as well as the increasing mobility across national borders demands a competence among people to live alongside and appreciate the values of cultural diversity' ... This film can be used as a starting point for discussions 
on the 'glocal' world, where global experiences meet and mix even in small villages ... (Pejkovic, 2018)

The study guide for Norwegian honour violence drama What Will People Say (2017) refers instead to the curriculum, stating that 'The film can be used for implementing your school's equality commitment, and also to deepen your work with the UN's declaration on human rights' (Halkawt, 2018). The study guide for Finnish road movie Little Wing (2016) also stresses the film medium's emotional impact: 'According to the curriculum, school education shall "encourage empathy and sympathy towards other people". To watch and discuss film ... is an unbeatable method to stimulate compassion and specify experiences and thereby strengthen empathy' (Larsson, 2018).

In summary, the introductory meta-discursive ingredients of the film study guides play an important role in processes of interpreting the film, as well as in informing how the study guides are used in the classroom. These meta-texts focus upon the thematic content of the films, and encourage the reader to allow students to discuss this further. When referring to the curriculum or the Education Act, the meta-texts almost exclusively emphasize how film education practices can be used as a way to make democratic value systems concrete.

\section{Themes and topics of the study guides}

An examination of the themes and topics within films that are brought up and elaborated in the study guides allows us to draw conclusions about what societal issues are considered crucial for students to engage with. Since film education in Sweden, I argue, is used primarily to foster young people's capacities as the democratic citizens of the future, it also provides information about what characterizes this 'ideal citizen'. I will discuss the two most frequently recurring themes - equality and human relationships - as well as their sub-themes.

By far the most frequent topic of the film study guides is equality in a broad sense: that is, the way the term is used in Article 1 of the United Nations' Universal Declaration of Human Rights: 'All human beings are born free and equal in dignity and rights' (United Nations, 1948). Almost all of the 12 examined texts not only bring up the theme of equality, but also develop the theme in numerous different ways. Divided into sub-themes sorted from most to least frequently recurring, the study guides discuss and evoke reflection on: gender equality, anti-racism, LGBTO rights, class differences and generational order. The most frequently recurring theme, gender equality, will be examined more closely.

Gender equality is explicitly or implicitly discussed in more than half (seven) of the study guides examined. The fact that none of the texts from 1988 mention this theme perhaps reflects the ways in which the 1980s was an era of backlash following the feminist movement of the 1970s (Ohlander and Strömberg, 2018). One of the films from the 1980s, Seppan, explicitly deals with girlhood and puberty, which makes the lack of gender issues in this study guide particularly notable. From 1998 onwards, however, the issue is frequently mentioned and in numerous ways. The 1990s 'girl power' movement had a great impact in Sweden, not least in terms of young and strident feminist debaters, new non-fiction literature and several 'amazon films' (films in which young women challenge patriarchal structures in a variety of ways) (Mulari, 2015). Lukas Moodysson's widely acclaimed debut film Show Me Love (1998), about two very different but equally passionate teenage girls, was clearly part of this movement. The Show Me Love study guide explicitly mentions the renewed interest in feminist issues of the 1990s, and even describes the film as a girl power story: 'Here, the girls 
dominate the pitch, demonstrate initiative and are in power. Elin and Agnes, alike, are strong characters ... In Show Me Love, the boys fall short' (Lagerström, 1998).

Fighter and What Will People Say also depict stories of young girls fighting prejudice against women's rights, freedom and abilities. Accordingly, the study guides accompanying these films provide considerably more in-depth, serious readings of gender issues. The text about Fighter states: 'Following the basic principle of every human being's equality and rights, expressed in the first article of the UN's Universal Declaration of Human Rights, every single person should call oneself a feminist. This is not the case, though' (Cojnby, 2008). The study guide introduces various feminist theories, referring to Simone de Beauvoir as well as Judith Butler, and raising questions such as 'What is the implication of the phrase [One is not born, but rather becomes, a woman]?' and 'Butler's theories might seem difficult and, above all else, many people find them provocative. What do you think? Are Butler's ideas hard to comprehend? What, according to you, do people find provocative about them?' (ibid.). One of the main themes of the What Will People Say study guide is to challenge the oversimplification of Islam's attitudes towards Western feminism. It focuses on the ambivalent relationship between a father and daughter, and also reflects upon stereotypical representations of women as victims:

The director/writer Iram Haq is said to have intended to break with stereotypes in an effort to create more complex characters. Do you interpret Nisha as a stereotypical victim, or has the director succeeded in her intent? If so, in what ways? (Halkawt, 2018)

In short, the study guides discuss, and encourage discussions about, issues of gender equality, and do so in a manner that is explicitly feminist. The anti-sexist and antipatriarchal approach is definitive and does not leave room for interpretation. The same, firm approach is taken in the study guides discussing and evoking reflections about anti-racism, LGBTQ rights, class differences and generational order. Without exception, the texts align with the minority and/or the group that is discriminated against.

The second most frequently discussed theme in the study guides examined is different kinds of human relationships, in turn divided into the sub-themes: friendship, family and kinship, and love relationships. Human relationships are brought up in 8 out of the 12 texts examined here, and it is a theme found in study guides from all four decades. This more intimate and emotional topic is addressed in a slightly different manner to the issues of equality discussed above.

As one might guess, Friends Forever is primarily a film about friendship, and correspondingly the main topic of the study guide is how to make and remain true friends. Following an exploration of the theme of friendship in the history of fine arts, the text raises the following, complex questions: 'What is the core problem of friendship? What is friendship usually defined against? Why do most stories of friendship and love also depict loneliness, grief, desolation and deceit?' (Viklund, 1988). The approach towards friendship as a theme is less philosophical in the Seppan study guide. The deep but complicated friendship between the protagonist girls Sara and Pirjo is described as a representation of the film's theme of class, since Sara is the daughter of the managing director of the factory where Pirjo's father (a Finnish immigrant with post-traumatic stress disorder after the Second World War) is employed. The economic differences between the girls are apparent, and manifested in a beautiful doll's dress, which Sara gives to her admiring friend: 
The blue [doll's] dress plays a crucial role in the friendship between the girls throughout the film. Try 'following' the dress across different scenes. What does it signify? What happens to the dress at the end of the film? What does it imply? (Edlund, 1988)

In the study guide accompanying Little Wing, family is rightly presented as one of the film's main topics. Fed up with her irresponsible and chaotic mother, 12-year-old Varpu takes off to find her father, whom she has not seen since she was a baby. Students are encouraged to put themselves in the protagonist's position and reflect upon her feelings towards her mother and father respectively, as well as considering what it would feel like if a parent forgot their birthday. Furthermore, they are asked to write a fictional letter, either from Varpu to her mother or the other way around (Larsson, 2018). Another film about family relations is the Swedish Patrik, Age 1.5 (2008), a story about a gay couple who accidently adopt a 15-year-old tough guy instead of a baby boy. Besides pinpointing prejudice against gay couples, the study guide focuses primarily on the teenager's family needs and the fragile trust growing between the boy and one of his prospective fathers. 'All children have the right to be loved', the study guide says, but 'For Patrik this is not the case' (Lagerström, 2008). Further on, the study guide raises the following questions:

Even if all parents assert their love for their children, this is not always true. In what way is Patrik an unwanted child? Do parents ever expect too much of their children? When imagining yourself as a future parent, what are your expectations of your own parenthood? (ibid.)

Although several of the films are about young people in love, the theme of romantic relationships is far less frequently highlighted in the study guides than friendship or family relations. The topic is mentioned in passing in the guides for Fighter and What Will People Say, and discussed a bit more extensively in the guides for Show Me Love and Friends Forever. The reasons for the lack of interest in love in the study guides are far from apparent, but there are at least two conceivable explanations: that love is not important enough to discuss in the classroom, or that it is assumed that too many students will find it hard to relate to the topic.

Overall, the study guides convey a sense that the decisive human relationships that film education practice ought to spread knowledge about are friendship and family relations. Thus, the ideal future citizen should endeavour to be an honest and loyal peer, as well as a loving and responsible parent.

\section{Addressing the reader}

To give a more complete picture of the film education practice recommended by the SFI, one needs also to analyse the way in which the study guides address a conceptualized reader. To do this, I will sketch some of the most prominent features of the semantic form of the study guides.

First, the film study guide is a somewhat vague and varying genre, oscillating between educational materials and cultural journalism, containing suggestions for lectures and hard facts, as well as film analysis. Irrespective of content, however, texts are characterized by three main attributes, here termed: (1) implied authority; (2) appeal to emotion; and (3) exclusionary presuppositions.

The notion of implied authority refers to the guides' recurring practice of raising seemingly open questions, to which there are in fact 'correct' (and, consequently, 'incorrect') answers. This is the tendency that Sparrman (2006) describes as 'a set 
political interpretive framework' when discussing Lilya 4-ever. There are countless illustrations of this implied authority in the study guides examined. Here is a selection from each of the four decades:

Does [the poor Venezulean boy] Pedro's home differ from a typical Swedish home, regarding for instance capital goods such as dishwasher, washing machine, car, television set and stereo? (Dahlén, 1988)

Is the story of Francie Brady a realistic depiction of a child's vulnerability and cruelty? Give examples of exaggerations or improbabilities in the story of Francie (Nyman, 1998).

To [the naive little boy] Bruno, the swastika, the concentration camp numbers and the cremation chambers lack meaning. How do you interpret the director's intention with the child's perspective? Is this an effective approach to expose the absurdities in a cataclysmic age? (Lagerström, 2010)

What atmosphere is created by the rainy, cold weather, the dark fir trees and the endless road that Varpu is travelling? ... What atmosphere would have been created by sunny, warm weather and the sound of birdsong and a cheerful tune? (Larsson, 2018)

The implicit existence of 'right' answers to the questions raised in the texts indicates that their originators (the SFI) do not trust the assumed reader's ability to draw his or her own conclusions. Additionally, it serves to underline my argument that there is a partially hidden agenda for the study guides: to lead students in a certain direction.

Perhaps to aid this 'directing', the implied authority of the texts is frequently combined with an appeal to emotion. As discussed above, film's ability as a medium to influence children and young people has explicitly been used as a 'fostering' tool in Sweden since The Children of Frosty Mountain was recognized as providing good role models. While this is seldom done as straightforwardly today as it was in the 1940s, the study guides still tend to treat the fictional characters of the films as real people of flesh and blood, which may be interpreted as a means of appealing to the reader's empathy. By approaching the protagonist as a friend, or even as if she or he were you, the text assists students in not only intellectually reflecting upon, but also in emotionally engaging with, the themes brought up by the film. Thus, the film medium is utilized as a true 'empathy machine', to quote the film historian and film-maker Mark Cousins (Cousins, cited in Janson, 2013: n.p.). As in the case of implied authority, there are many examples of appeals to emotion in the study guides:

How come Kristian hasn't got the courage to be himself? Is Kristian afraid of being rejected? Why? (Viklund, 1988)

What does Alex feel entering into his hiding place in the cellar? (Westergren, 1998)

If you were Aicha's father, what would your attitude have been? (Cojnby, 2008)

What gives her [Nisha] the courage to finally break up? (Halkawt, 2018)

This appeal to emotion can also be an approach designed to get students to open up and, indirectly, to reflect upon themselves. Film education practice as a way to enhance self-understanding has a long heritage in Sweden, and is persistently emphasized 
by experienced film pedagogue Eva Westergren (2016). In psychological terms, this practice might be referred to as de-focusing, that is, a way to get to know yourself by reflecting upon somebody else's thoughts, feelings and actions (Raundalen and Schultz, 2010).

The third main attribute characterizing the study guides occurs less frequently, but it is still noteworthy. The use of exclusionary presuppositions is related to implied authority and the appeal to emotions and, in a way, connects these semantic attributes together. It is best described as a way to imply the existence of a 'we' that includes and connects the originator and the reader of a text. The author of the study guide takes for granted that the readers - and, by extension, the students - are just like her or him. In some cases, these presuppositions exclude the very minorities that, according to the same study guides, have the same rights to be included and respected as those in the majority. In Show Me Love, for instance, lesbianism is noted as something expressly 'different', and is treated as such in the questions directed to students: 'Love is complicated and homosexual love is even harder to talk about, and even accept for some people. How is this manifested in Show Me Love?' (Lagerström, 1998). According to this, there is (heterosexual) 'love' and then there is 'homosexual love', underlining otherness as a deviation from the norm. The Fighter study guide is more nuanced than this, and even discusses problematic stereotypes and hasty conclusions. Yet, it asks the question, 'What is your conception of a woman's role within Islam?', as if none of the students asking themselves the question might actually be a Muslim (Cojnby, 2008).

To summarize, the study guides produced by the SFI since 1988 are of vital importance, since the subjects discussed in these texts are the subjects that have been most frequently discussed in classrooms across the country. Therefore, the study guides provide key information about the 'fostering' discourses of Swedish film education. The analysis carried out here demonstrates that the most frequent thematic focus concerns the basic human right to equality and human relationships. Furthermore, these subjects are described in a manner closely corresponding with the curriculum, which, in turn, reflects the basic principles of Swedish democracy. In theory, there is little or no room for 'deviant' interpretations or opinions in the classroom. This is further consolidated by the semantic qualities of the study guide texts, such as an implied authority and an appeal to emotion that, taken together, produce a convincing argumentation.

\section{Conclusion and final reflections}

The main aim of this article has been to demonstrate a film educational approach that utilizes fiction film as a moral educational tool and has the more or less openly declared intention of moulding students into democratic citizens. This approach towards cinema differs from the cinephilic French approach, centring on cinema as an art form, as well as from the German Medienkompetenz approach, centring on media education (Henzler, 2018). I have argued that this Swedish variety of film education can be traced back to the 1940s, when children's cinema was considered an excellent instrument for bringing moral education to a young audience, and hence fostering good future men and women for a prospering Swedish state. Among the core traits befitting this imagined citizen were honesty, respect, humbleness and sobriety, as well as empathy and generosity - a set of ideals embodied by Ante and Maglena, protagonists and role models of The Children of Frosty Mountain. While one might assume that what is considered to characterize a good citizen varies over time, the results of my analysis of film study guides produced between 1988 and 2018 show that this does not seem 
to be the case. On the contrary, the views and attitudes encouraged by the study guides are very similar to those of Ante and Maglena. This might be interpreted as a reflection of the relative stability that has distinguished the Swedish nation over the last sixty years.

In my PhD thesis, I describe Swedish children's film as 'a cinema of best intentions' (Janson, 2007). Likewise, I would state that Swedish film education practice is a film education of best intentions, since its main aim - unlike in many other countries - is to mould children and young people into good, democratic citizens. One might even call this a 'Swedish model'. Whether or not this method is adequate or suitable is obviously disputable, and I would argue that there are two most apparent problems of this model.

First, one can ask if this kind of 'civic fostering' film education really 'works', or whether it is, in fact, very naive. I cannot help but think of the student who does not identify with the ideal youngster promoted by the study guides - that is, he or she does not feel included in the 'we' referred to above. Or, for that matter, the student who does not agree with the values that the study guides take for granted - that is, he or she does not provide the 'right' answers to the questions raised. Do we really think that film education can turn a sexist into a feminist and a racist into an anti-racist? Is it really that easy? I am unsure, but I have strong doubts.

Second, even if this kind of 'fostering' film education 'works' as a tool to mould young people, do we want it to? Do we really intend to use our adult power over the young to influence their thoughts and opinions in this way - to provide students with the 'right' answers instead of encouraging free thinking? And, closely connected to these issues, who decides which answers are the 'correct' ones? I cannot help reflecting upon the use of political propaganda and what would happen if film education was used to implant 'wrong' ideas - anti-egalitarian, or even fascist? Sweden has been a stable democracy for one hundred years, but that does not mean that will always be the case. On the contrary, just as in the rest of the Western world, there are - at this point in history - tendencies that would seem to point in the opposite direction.

While what I have designated as the 'Swedish model' has largely dominated film education practices and discourses in Sweden since the 1980s, there may be evidence of a contemporary shift. More recent study guides, such as those from 2018, seem to present a slightly different, or expanded, approach to film education as a practice. The Swedish model is still dominant, but it has been extended with features of the cinephilic, as well as of the Medienkompetenz, approach. For instance, the SFI recently launched the film educational project Cinematheque: School, aiming to make film history available and known to children. Furthermore, the recent study guides produced by the SFI more often cover media-specific elements of films, such as the relationship between fiction and reality, emotional impact and the camera as weapon.

Finally, as mentioned at the outset, a more general aim of this article has been to add to the mapping and understanding of the history, discourses and practices of film education in Europe. By learning about different national models, we can seek inspiration in discovering and developing new approaches towards cinema as an art form, a language and a tool for democratic education. Fortunately, these different approaches do not rule each other out. 


\title{
Acknowledgements
}

Many thanks to my friend and former colleague Per Eriksson for reading, cheering and delivering hard facts.

\section{Notes on the contributor}

Malena Janson is a senior lecturer at the Centre for the Study of Children's Culture at Stockholm University. Among her research interests are representations of children and childhood in film and television, and film education focusing on cinema as an art form and/or an educational tool. From 2012 to 2017 she worked at the Swedish Film Institute. She is editor and co-author of the anthology Introduktion till filmpedagogik ('Film Education: An introduction'), published by Gleerup in 2014.

\section{Filmography}

\author{
Amateurs (SE 2018, Gabriela Pichler) \\ The Children of Frosty Mountain (SE 1945, Rolf Husberg) \\ Fighter (DK 2007, Natasha Arthy) \\ Friends Forever (DK 1986, Stefan Henszelman) \\ Gandhi (GB/IN 1982, Richard Attenborough) \\ The Island on Bird Street (DK 1997, Søren Kragh-Jacobsen) \\ The Last Emperor (GB/IT 1987, Bernardo Bertolucci) \\ Lilya 4-ever (SE/DK 2002, Lukas Moodysson) \\ Little Revenge (VE 1986, Olegario Barrera) \\ Little Wing (FI 2016, Selma Vilhunen) \\ Patrik, Age 1,5 (SE 2008, Ella Lemhagen) \\ Seppan (SE 1986, Agneta Fagerström-Olsson) \\ Show Me Love (SE 1998, Lukas Moodysson) \\ What Will People Say (NO 2017, Iram Haq)
}

\section{References}

Cojnby, E. (2008) 'Fighter'. Swedish Film Institute. Online. https://tinyurl.com/y5rw9hfg (accessed 11 August 2019).

Dahlén, P. (1988) 'Pedros svåra uppdrag/Little Revenge'. Swedish Film Institute.

Dahlquist, M. (2008) 'Upplysning'. In Koivunen, A. (ed.) Film och andra rörliga bilder: En introduktion. Stockholm: Raster Förlag, 40-54.

Edlund, E. (1988) 'Seppan'. Swedish Film Institute.

Eriksson, P. (2016) 'Introduktion till filmpedagogik'. In Janson, M. (ed.) Introduktion till filmpedagogik: Vita duken som svarta tavlan. Malmö: Gleerups, 15-24.

Exadaktilou Wallenrodhe, N. (2018) 'Addressing "Non Suitable" Films in School: A case study on Flickan, mamman och demonerna and the film pedagogic conditions'. Unpublished MA thesis, Stockholm University.

Halkawt, K. (2018) 'Vad ska folk säga'. Swedish Film Institute. Online. https://tinyurl.com/y3wk7dyd (accessed 11 August 2019).

Henzler, B. (2018) 'Education à l'image and Medienkompetenz: On the discourses and practices of film education in France and Germany'. Film Education Journal, 1 (1), 16-34.

Holmberg, O. (1988) Videovåld och undervisning. Stockholm: Symposion.

Holmberg, O. (2016) 'Filmpedagogik och kunskapssyn'. In Janson, M. (ed.) Introduktion till filmpedagogik: Vita duken som svarta tavlan. Malmö: Gleerups, 35-43.

Janson, M. (2007) 'Bio för barnens bästa? Svensk barnfilm som fostran och fritidsnöje under 60 år'. Unpublished PhD thesis, Stockholm University.

Janson, M. (2008) 'Fostran'. In Koivunen, A. (ed.) Film och andra rörliga bilder: En introduktion. Stockholm: Raster Förlag, 123-43. 
Janson, M. (2013) '“Filmen är en empatimaskin"'. Swedish Film Institute. Online. https://tinyurl.com/y2evw2v9 (accessed 11 August 2019).

Karlsson, M. (2011) 'Att projicera det förflutna: Historiebruk och historieförmedling i svensk skolfilm 1970-2000 utifrån de regionala AV-centralernas utbud'. Unpublished PhD thesis, Mid Sweden University.

Lagerström, L. (1998) 'Fucking Åmål/Show Me Love'. Zoom, 10 (4), 42-5.

Lagerström, L. (2008) 'Patrik 1,5'. Swedish Film Institute. Online. https://tinyurl.com/y35lvepm (accessed 11 August 2019).

Lagerström, L. (2010) 'Pojken i randig pyjamas'. Swedish Film Institute. Online. https://tinyurl.com/y3on6tv5 (accessed 11 August 2019).

Larsson, M.K. (2018) 'Little Wing'. Swedish Film Institute. Online. https://tinyurl.com/y66xppj8 (accessed 11 August 2019).

Lindgren, A.-L. (2009) 'Visualiseringen av naturen i tidig svensk skolfilm'. In Halldén, G. (ed.) Naturen som symbol för den goda barndomen. Stockholm: Carlsson, 34-58.

Lindgren, A.-L., Sparrman, A. and Eriksson Barajas, K. (2012) 'From instruction to reflection: Film in education in Sweden'. In Cheung, C. (ed.) Research in Media Education. New York: Nova Science Publishers, 151-73.

Mulari, H. (2015) 'New Feminisms, Gender Equality and Neoliberalism in Swedish Girl Films, 1995-2006'. Unpublished PhD thesis, Åbo University.

Nyman, A. (1998) 'Butcher Boy'. Zoom, 10 (4), 38-41.

Ohlander, A.-S. and Strömberg, U.-B. (2018) Tusen svenska kvinnoår: Svensk kvinnohistoria från vikingatid till nutid. Lund: Studentlitteratur.

Pejković, S. (2018) 'Amatörer'. Swedish Film Institute. Online. https://tinyurl.com/y62wowqv (accessed 11 August 2019).

Raundalen, M. and Schultz, J.-H. (2010) Kan vi prata med barn om allt? De svåra samtalen. Lund: Studentlitteratur.

Rozenkrantz, J. and Mund, M. (2014) 'Alltid redan en aktivitet: Åskådarskap och estetiska lärprocesser'. In Burman, A. (ed.) Konst och lärande: Essäer om estetiska lärprocesser. Huddinge: Södertörns högskola, 405-25.

SOU (Statens offentliga utredningar) (1945) Ungdomen och nöjeslivet. Ungdomsvårdskommitténs betänkande del III (1945:22). Stockholm: Statens offentliga utredningar.

Sparrman, A. (2006) 'Film as a political and educational device: Talk about men, male sexuality and gender among Swedish youth'. Visual Studies, 21 (2), 167-82.

Swedish Film Institute (n.d.) 'Film in schools'. Online. https://tinyurl.com/yxkwyszm (accessed 11 August 2019).

United Nations (1948) 'Universal Declaration of Human Rights'. Online. www.un.org/en/universal-declaration-human-rights/ (accessed 7 March 2019).

Viklund, K. (1988) 'Vänner för alltid/Friends Forever'. Swedish Film Institute archive.

Viklund, K. and Österholm, C. (2001) Skolbio i Sverige: En kartläggning av verksamheten med barnoch skolbio i Sveriges 289 kommuner, genomförd av Svenska Filminstitutet 2000. Stockholm: Swedish Film Institute.

Westergren, E. (1998) 'Ön i Fågelgatan/The Island on Bird Street'. Zoom, 10 (1), 56-9.

Westergren, E. (2016) 'Att nå det fördjupade samtalet'. In Janson, M. (ed.) Introduktion till filmpedagogik: Vita duken som svarta tavlan. Malmö: Gleerups, 61-74. 